ӘОЖ 94(574):925

FTAXP 03.20

DOI 10.37238/1680-0761.2021.83(3).16

\author{
${ }^{1}$ Рысбеков Т.3., ${ }^{2}$ Куандихова С.А.* \\ 1,2М.Өтемісов атындағы Батыс Қазақстан университеті, Орал, Қазақстан \\ *Корреспондент авторы: kuandikhova@mail.ru
}

E-mail: tuyakbai.rysbekov@ mail.ru, kuandikhova@mail.ru

\title{
САНЖАР АСФЕНДИЯРОВТЫН ӨМІР ЖОЛЫ МЕН ҚЫЗМЕТІ
}

\begin{abstract}
Аңдатпа. Мақ̧алада туван елінің көгіне жұлдызы жарққырап шыққан құазаққтың ардақты ұлы, қъовам және мемлекет құайраткері, көреген саясаткер, дарынды валым, педагог, әрі жазушы , Қазақсстанда вылым мен білім беру ісінің білгірі және шебер ұйымдастырушы Санжар Асфендияров өмірі мен қыззметі туралы баяндалван. Оның құазақ мемлкетінің құалыптасуы мен дамуына, білім беру жүйесі мен вылымынн, денсаульққ сақтау саласына қ̧осқ̧ан үлесі ұшаң теңізі.

Санжар Асфендияров дүйім қ̧азақта аты белгілі тұлzаларадың жұрнавы, болаттай тұяzы іспеттес. Әкесі Сейітжапар - сұлтан, Әбілхайыр ханның үлкен ұль Айшуақ ханның ұрпавынан тараван патша әскерінің полковнигі шенінен отставкава шыққан, жарты zасырдан астам уақыт Түркістан өлкесінде қыызмет еткен құзақ құайраткері, анасының есімі Гүландам Қасымова. Өзінің жарты васырдан астам мерзімге созылван қызмет жолын қатардавы порукчиктен баставан Санжар Асфендияров туа біткен дарыны мен еңбекқорлывының арққасында Түркістан өлкесінің түркі - мұсылман халықтары үшін жовары әскери атақ болып саналван - полковник шеніне қол жеткізеді.
\end{abstract}

Кілт сөздер: тарих вылымы, галым, дәрігер, зерттеу, шыгарма, монография, педагог, саясаткер, алашорда, саясат.

\section{Kipicne}

Тәуелсіздік жылдары отандық тарих ғылымының қол жеткізген табыстары мен жетістіктері аз емес. Қазақ халқының тарихы қайта қаралып, оның объективті және субъективті себептердің салдарынан бұрын жасырынып келген ақтаңдақ беттері ашылды. Қазақ мемлекеттілігінің қалыптасуына, қазақ халқының мәдениеті мен салт - дәстүрін, жері мен тілін сақтап қалу жолында аянбай тер төгіп, халқына адал қызмет еткен ұлт зиялыларының идеялары мен тарихи мұралары қайта жаңғырып, олардың өмірлері мен қызмет жолдары зерттелінді.

Қазіргі отандық тарих ғылымының өзекті бағыттарының біріне айналған тұлғатану саласы қарқынды дамып келе жатқанына қарамастан, бар саналы ғұмырын туған халқына қызмет етуге арнаған ұлт зиялы қауымының жекелеген топтары мен жарқын өкілдері зерттеушілердің назарына әртүрлі саяси - идеологиялық себептердің салдарынан назардан тыс қалды. Мұндай қайраткерлердің қатарына дарынды ғалым, ұлағатты ұстаз, ірі қоғам және мемлекет қайраткері Санжар Сейітжафарұлы Асфендияровты жатқызуға болады.

С.Асфендияровтың 1938 жылы сталиндік қуғын - сүргіннің жазықсыз жапа шеккен құрбанына айналып, «халық жауы» деп негізсіз айыпталуына байланысты ғалым тарихшылар көпке дейін оның өмірі және қызметімен, бай ғылыми - тарихи және шығармашылық мұрасымен танысу мүмкіндігінен айырылды. Кеңес билігі тұсында С.Асфендияровтың өмірі мен қызметіне қатысты тарихи құжаттар мұрағаттардың арнайы қорларында сақталынып, оның ғылыми еңбектерімен танысуға ресми түрде тиым салынды. 
Тәуелсіз кезеңде де С.Асфендияровтың өмірі мен қызметін кешенді түрде зерттеу отандық тарихшылардың тарапынан түрлі объективті және субъективті себептердің салдарынан қолға алынбады. Бұған ең алдымен қайраткердің 1928 жылға дейінгі мемлекеттік және ғылыми - педагогикалық қызметі Қазақстаннан тыс жерде өтуі ықпал етті. Оның қайраткерлік жолын және тұлғалық келбетін ашып бере алатын құжаттар Өзбекстан мен Ресейдің мұрағаттарында сақталынып қалуы тарихшыларға С.Асфендияровтың өмірі мен қызметін тұтас әрі кешенді түрде зерттеуге айтарлықтай кедергі келтірді. Өйткені осы мұрағат құжаттарды алдырту күрделі де шығынды іс.

\section{Зерттеу материалдары мен ддістері}

Мәселелерді ғылыми тұрғыдан ашып көрсету мақсатында тарихи зерттеудің диалектикалық тәсілдерімен тығыз байланыстығын тарихилық, объективтілік сияқты негізгі методолгиялық қағидалар басшылыққа алынды.

С.Асфендияровтың 1889 - 1937 жылдар аралығындағы сан салалы қоғамдық - саяси және мемлекеттік қызметінің зерттелу тарихын екі негізгі кезеңге бөліп қарастыруға болады. Кеңестік кезеңде отандық тарихнамада С.Асфендияровтың өмірі мен қызметі үстіртін ғана зерттелініп, тұрақты сипатқа ие болмады. 1950 жылдың аяғында - 1960 жылдың басында С.Асфендияровтың өмірі мен қызметін жан - жақты зерттеуге Қазақ КСР Ғылым академиясы Тарих, археология және этнография институтының аспиранты Р.Сүлейменов кірісе бастаған болатын. 1959 жылы Р.Сүлейменов алдымен Қазақ КСР ҒА хабаршысында «О научной деятельности С.Асфендиярова» атты мақаланы [1], артынан «Алма-Атинская правда» газетінде «Видный общественный деятель и ученый» атты мақаланы [2] жариялап, оларда қысқаша түрде С. Асфендияровтың қайраткерлік жолына және еңбектеріне тоқталып өтеді $[3,6.6]$.

1970-ші жылдары С.Асфендияровтың өмірі мен қызметін зерттеу ісі тоқтап қалған болатын. Қарастырылып отырған кезеңде мерзімді баспасөз беттерінде тек Ж.Ауыпбаевтың «ҚазПИ-дің алғашқы ректоры» атты шағын мақаласы ғана жарияланып, онда қайраткер туралы бұрынан белгілі мәліметтер келтірілді.

1980-ші жылдары С.Асфендияровтың есімі мен қысқаша өмірбаяны түрлі академиялық және анықтамалық басылымдарға тұрақты түрде ене бастайды. Мысалы, С.Асфендияровтың өмірбаяны «Алма-Ата» атты энциклопедиялық анықтамалыққа [4], «Алғашқы қазақ дәрігерлері» [5] және «Библиография обществоведов Казахстана» [6] атты қысқаша өмірбаяндар жинақтарына кірген болатын.

Кеңес дәуіріндегі қайраткердің өмірі мен қызметін зерттеу ісінің алға басуына 1989 жылы қазан айында Алматы қаласында Ш.Уәлиханов атындағы Тарих және этнология институтының, Абай атындағы Қазақ Ұлттық педагогикалық университетінің және С.Асфендияров атындағы медицина университетінің бірлесіп, С.Асфендияровтың 100жылдық мерейтойына арналып өткізген ғылыми конференция айтарлықтай үлес қосты.

1990-шы жылдары әл-Фараби атындағы ҚазМУ профессоры Ә.Такеновтың ұйымдастыруымен С.Асфендияровтың «История Казахстана (с древнейших времён)» және «Прошлое Казахстана в источниках и материалах» атты ғылыми еңбектері 1993 жылы, «Қазақстан тарихының очерктері» атты оқу құралы 1994 жылы қайта жарық көріп, көпшілік оқырманға жол тапты.

2009 жылы қарашада Абай атындағы ҚазҰПУ-дың А.Байтұрсынов атындағы Алаш зиялыларының ғылыми-педагогикалық мұрасын зерттеу орталығы ғылыми қызметкерлерінің ұйымдастыруымен С.Асфендияровтың 120-жылдық мерейтойына орайластырып ғылыми конференция өткізілді. Аталған конференцияда Санжар Асфендияровтың өмірі мен қызметі туралы тарихшылар О.Қоңыратбаев, Д.Мұқатова, Т.Нұрпейісов, Б.Берлібаев баяндама жасады. Конференцияның жарық көрген материалдары Санжар Асфендияровтың қайраткерлік жолын, ғылыми - педагогикалық қызметін зерттеуге, оның қазақ халқының тарихына қатысты алға тартқан ой-пікірлері мен тұжырымдарын танып білуге өз үлесін қосты [3, б.11]. 


\section{Зерттеу натижелері}

Санжар Асфендияров 1889 жылы 20 қазанда Ташкент қаласында дүниеге келген. Оның шығу тегіне қатысты біршама толық мәліметті беретін құжаттардың бірі - әкесі Сейітжапар Асфендиярұлының 1898 жылы өз қолымен жазған өмірбаяны болып табылады. Құжат мәліметтері Сейітжапардың Кіші жүз қазақтарының ханы Әбілқайырдың төртінші ұлы Айшуақ ханның шөбересі екендігін көрсетеді.Асфендияр сұлтанның ұлы Сейітжапар Түркістан өлкесінің тұрғылықты халқы арасынан ұзақ жылдар бойы жергілікті отарлық әкімшілікте қызмет етіп, орыс әскерінің жоғарғы офицерлік құрамына іліккен, полковник шеніне қол жеткізген көзі ашық, сауатты адам болған. Ол жұбайы Гүләндамен бірге сегіз баланы тәрбиелеп, олардың барлығына мүмкіндіктері келгенше уақыт талабына сай орта және жоғары білім беруге тырысты [3, б. 38-39].

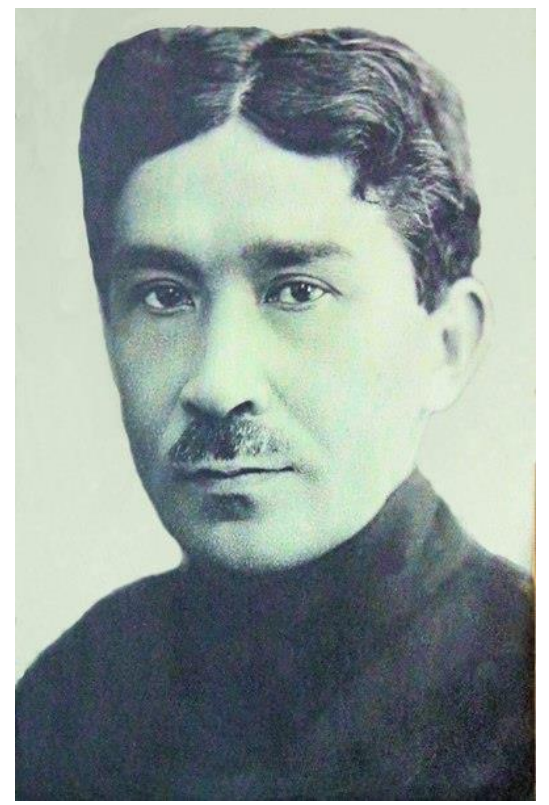

1-Сурет - Санжар Асфендияров, автормен [3, б. 73] ддебиетінен альнван

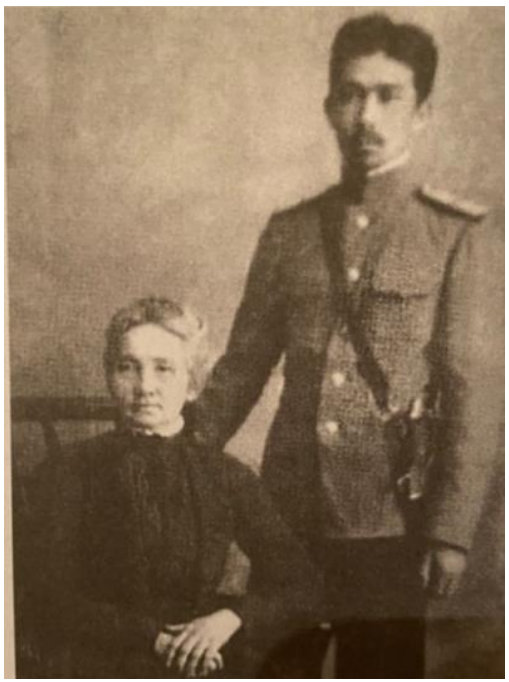

2-Сурет. Студент Санжар Асфендияров анасы Гүләнда Қасымовамен, автормен [3, б. 73] ддебиетінен альндан 

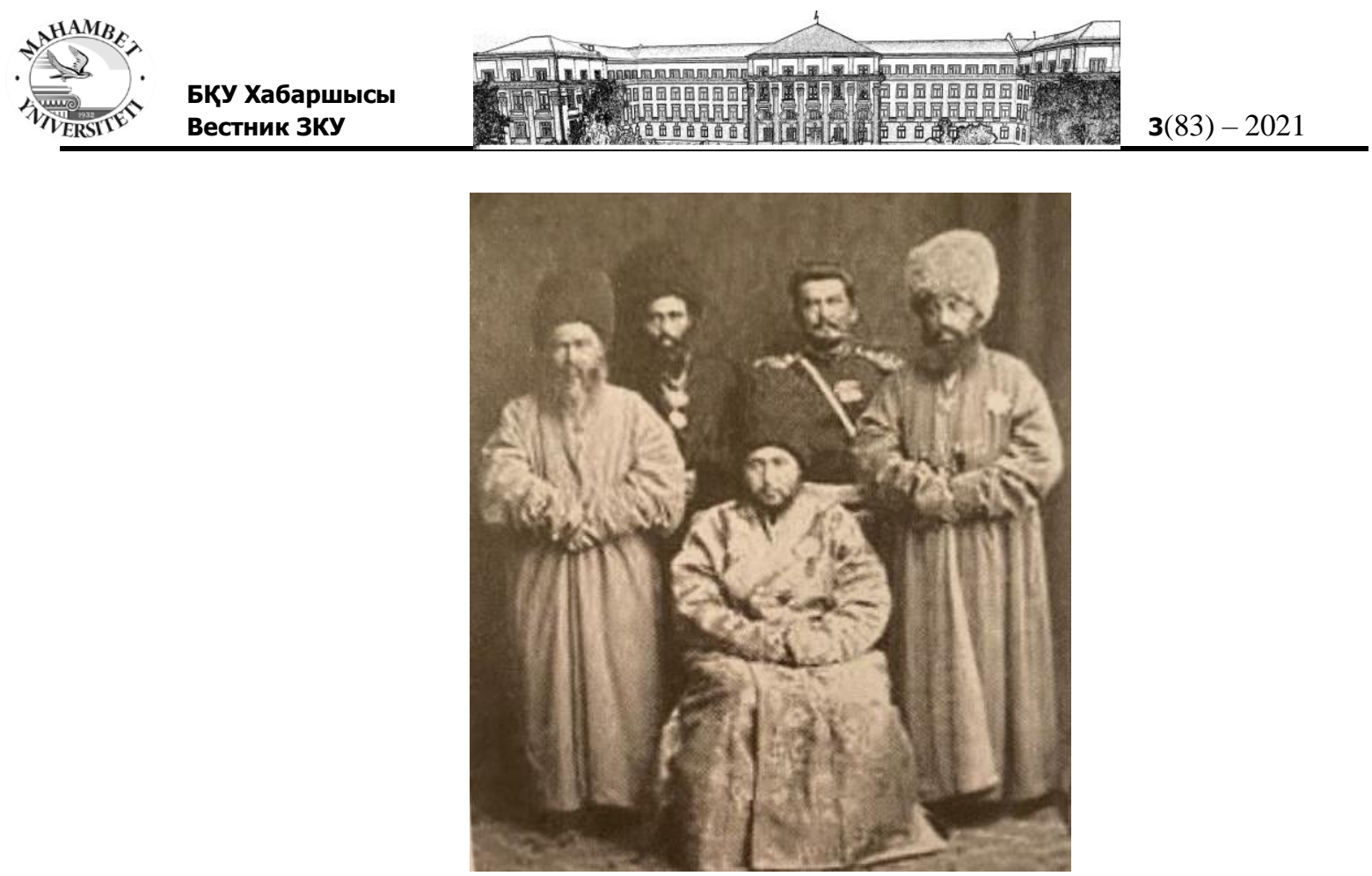

3-Сурет. Санжардың әкесі - Сейітжапар Асфендиярұльы өзінің туыстарымен бірге, автормен [3, б. 74] ддебиетінен альнван

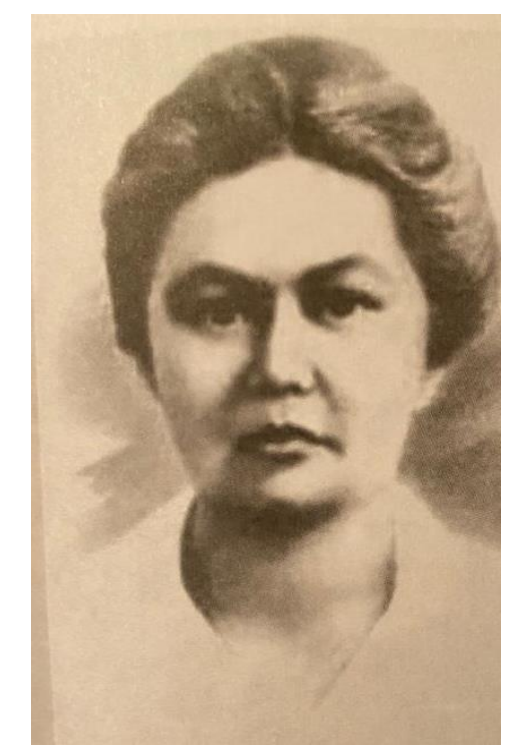

4-Сурет.Умми-Гүлсім Асфендиярова , бірінші дәрігер қ̧азақ қ̧ызы, Санжсардың әпкесі, автормен [3, б. 74] ддебиетінен альндан

Сейітжаппар Асфендиярұлы кенже ұлы Санжарды 1898 жылы Ташкент реалды училищесіне арыз жазып, оқуға түсіреді. Бұл уақытта училищенің қабырғасында оның ағасы Нұреддин білім алып жатқан еді.

Жасынан зерек те қабілетті Санжардың орыстандыру саясатына көнбей, керісінше училище қабырғасында азаматтық білім алып, отаршылдыққа қарсы рухта өсіп жетілгендігіне кейінгі саналы өмірі мен қайраткерлік қызметі айқын дәлел бола алады. Оның қабырғасында оқып жүрген жылдары Санжар ұлттық теңсіздік пен құқықсыздықтың ащы дәмін тартады. Жергілікті халықтың өкілі ретінде Санжар өзге реалистермен бірге латын тілін оқуға қатыстырылмады. Осының кесірінен, Санжар 1907 жылы Петербор Мемлекеттік университетінің студенті атану құқығына қол жеткізе алмады. Өзінің ең алғашқы саяси өмір 
мектебіне айналған реалды училищені Санжар 1907 жылы 5 маусымда аяқтап, қолына бітіру куәлігін алды [7, б.110].

1907 жылдың маусымында Санжар жоғары оқу орындарының біріне оқуға түсу мақсатын көздеп, Петереборға аттанады. Алайда, «орта білім алғаны туралы куәлікте латын тілі мен дін сабағы («Закон божий») бойынша бағасы жоқ» деген сылтаумен емтиханға жіберлмейді. Ұлының оқуға түсуіне көмек көрсетуге талпынған Санжардың әкесі Сейітжапар Түркістан генерал - губернаторы Н.И.Гродековқа өтініш хатжазады. Генерал Н.И. Гродеков Сейітжапардың еңбегі сіңген қайраткер екендігін, сондай - ақ академияға түсуге талпынып жатқан Санжардың түркі - мұсылман халықтары арасынан болашақта дәрігер шығатынын ескеріп, әскери министр А.Ф. Редигерге Санжарды оқуға қабылдаудың қажеттігі туралы өтініш - хат жолдайды. Осылайша, академияның қабылдау комиссиясы Санжар Асфендияровқа алғашқы семестрде латын тілінен сынақ тапсыруды шарт етіп қойып, оны ерікті тыңдаушы ретінде оқуға қабылдайды [7, б.111].

1907 жылы қарашада латын тілін бойынша сынақтан сүрінбей өткен Санжар империядағы үздік жоғары орындарының бірі болған Императорлық әскери - медициналық академияның толыққанды студенті атанып, XIX ғасырдың аяғы - XX ғасырдың басында империяның үздік оқу орындарында жоғары білім алған алдынғы қатарлы қазақ жастарының қатарына қосылды. Санжар 1907 жылы әскер - медициналық академияға оқуға түскен кезде оның қабырғасында үш қазақ баласы - Халел Досмұхамедов, Нұрғал Ипмғанбетов және Сәдуақас Шалымбеков білім алып жатты. Бұл үшеуі де 1910 жылға дейін академиядағы өз оқуларын аяқтап міндетті әскери - медициналық қызметті атқаруға кіріседі [7, б.111].

1910 жылы С.Лапиннің қызы Рабиғаға үйленеді. 1914 - 1915 жылдары бірінші дүниежүзілік соғысқа қатысқан. 1917 жылы Бұхарадағы мұсылман қозғалысына белсене араласты. Сол жылдың қараша айында Түркістан автономиясын («Қоқан автономиясын») жариялаған Мұсылман депутаттарының төтенше съезіне қатысады. 1918 - 1919 жылдары Асфендияров аштықпен күрес жөніндегі Төтенше комиссияның Сырдария облысы бөлімшесін басқарады. 1919 жылғы қыркүйекте Т.Рысқұловтың шақыруымен Ташкентке келіп, Түркістан АКСР-нің Денсаулық сақтау халкомы, Жер халкомы, Түркістан Компартиясы ОК- нің хатшысы қызметтерін атқарған [8, б. 138].

Ұлттық аумақты межелеу тұсында (1924 - 1925 жылдары) Ортаазиялық Федерация құру идеясын ұстанды. 1924-1925 жылдары Қазақ АКСР-нің Өзбек АКСР үкіметі жанындағы өкілетті өкілі, 1925-1928 жылдары Мәскеуде - Бүкілодақтық атқару комитетінің (БОАК) Төралқа мүшесі, хатшысының орынбасары, Мәскеу мемлекеттік университетінің профессоры, Н.Нариманов атындағы Шығыстану университетінің директоры болды [8, б. 139.].

Қайраткердің 1925-1928 жылдар аралығында КСРО астанасы - Мәскеу қаласында атқарған сан - салалы қызметі осы күнге дейін арнайы ғылыми зерттеудің нысанына айнала қойған жоқ. С.Асфендияровтың өмірі мен қызметінің осы кезеңіне қатысты қалам тартқан ғалым-тарихшылардың еңбектерінде оның қайраткерлік жолына тек үстіртін немесе жанама тоқталып өткен жоқ. Бұған ең алдымен С.Асфендияровтың Мәскеудегі қызметін жан жақты ашып бере алатын негізгі құжаттардың басым көпшілігі Ресей Федерациясы мемлекеттік мұрағатының қорларында сақтаулы тұрғандығы, сондай - ақ осы мұрағаттардан құжаттарды алдырту күрделі де шығынды іс екені басты себеп болып тұр.

1925 жылдың сәуір айының аяғына дейін Қазақ АКСР-нің Орта Азиядағы өкілетті өкілі міндетін атқарып келген С.Асфендяиров 60-тан астам адамнан құралған қазақ делигациясының құрамында Мәскеу қаласына келеді. 27-29 сәуірде С.Асфендияров алдымен РКП (б) XIV партиялық конференцияға Қазөлкекомның атынан кеңесші дауыспен қатынасса, артынан мамыр айында XII Бүкілресейлік кеңестер съезінің және III Бүкілодақтық кеңестер съезінің жұмысына араласады.

1925 жылы 7-16 мамыр аралығында өткен XII Бүкілресейлік кеңестер съезіне 1634 делегат, соның ішінде 1634-і шешуші дауыспен, 550-і кеңесші дауыспен қатынасты. Съездің 
күн тәртібіне төмендегідей мәселелер белгіленді: РКФСР үкіметінің баяндамасы; РКФСР Конституциясының мәтінін өзгерту; Түркістан АКСР-нің РКФСР құрамынан шығуы, Өзбек және Түркімен одақтас республикаларының құрылуы. Бүкілресейлік съездің толық құрамы III Бүкілодақтың кеңестер съезінің жұмысына қатынаса алу үшін РКП (б) фракциясының ұсынысымен күн тәртібінен РКФСР үкіметінің баяндамасы алынып тасталды. Жалпы алғанда, съез делегаттары РКФСР-дың жүргізіп отырған ішкі және сыртқы саясатына қолдау білдірді. Сонымен қатар, съез ХІ шақырылымдағы РКФСР БОАК II сессиясының 1924 жылы 14 қазанда Түркістанды мекен еткен қазақ, өзбек, тәжік, түркімен, қырғыз халықтарына Түркістан АКСР-нің құрамынан шығу және ұлттық белгі бойынша республикалар мен облыстарды құру құқығын беру туралы қауысын мақұлдады [9, б. 58 - 59].

Съездің қортындысында РКФСР БОАК-тың құрамына Қазақ АҚСР-нен С.Асфендияров, Қ.Әуезов, И.Каширин, Ы.Көшкінов, К.Кравец, С.Қожанов, Ж.Мығбаев, В.Нанейшвили, А.Самсонов, А.Толоконцев мүше ретінде, ал Н.Ежов, М.Орумбаев және А.Оразбаева мүшелікке кандидат болып сайланды. Жоғарыда есімі аталған қызметкерлердің ішінен С.Асфендияров және А.Толоконцев БОАК төралқасының құрамына сайланып, Орталықта қызметте қалдырылды.

Бүкілресейлік кеңестердің кезекті съезі аяқталсымен, қазақ делегациясы толық құраммен 13-20 мамыр аралығында өткен Бүкілодақтық кеңестердің III съезіне қатынасады. Бұл съездің жұмысына шешуші дауыспен Қазақ АКСР-нан С.Асфендияров та белсене араласқан болатын. Съездің қортындысында С.Асфендияров РКФСР БОАК-тың мүшесі ретінде КСРО Орталық Атқару Комитетінің құрамына сайланады. 1925 жылы 21 мамырда өткен КСРО Орталық Атқару Комитетінің I сессиясында С.Асфендияров КСРО ОАК Ұлттар Кеңесінің хатшысы қызметіне тағайындалды [9, б. 59].

1925 жылы 11 мамырда өткен XII шақырылымдағы БОАК-тың I сессиясында С.Асфендияров БОАК хатшысы А.Киселевтің орынбасары және БОАК төралқасы жанындағы Ұлттар бөлімінің меңгерушісі қызметінде тағайындалды. Осы күнге дейін отандық және ресейлік тарихнамада Санжар Асфендияров БОАК-тың Ұлттар бөлімінің меңгерушісі қызметін 1926 жылдың басынан бастап атқара бастағандығы туралы қате мәлімет кездеседі. Тарихшылар Д. Аманжолова мен В.Чеботарева өз ғылыми еңбектерінде Санжар Асфендияровтың ұлттар бөліміне басшылықты 1926 жылдан бастап жүргізе батады деген мәліметтерді келтіреді. Алайда, Ресей федерациясының мемлекеттік мұрағатының 1235-шы (ВЦИК) қорынан табылған құжаттар бұл мәліметтерді жоққа шығарады. Мысалы, БОАК хатшылығының 1925 жылдың 14 шілдесінде өткен мәжілісінде Ұлттар бөлімінің меңгерушісі С.Асфендияровтың бір айлық демалысқа кетуіне байланысты оның қызметін уақытша атқарушы болып Р.Сабировтың тағайындалғандығы туралы қаулы қабылданған. Сонымен қатар, БОАК төралқасының 1925 жылдың 23 шілдесінде өткен мәжілісте БОАК хатшысы А.Киселевтің және орынбасарлары қызметінде жұмыс істеген С.Асфендияров пен Я.Полуян арасында міндеттерді анықтау мәселесі қарастырылды. Мәжіліс А.Кисилевке БОАК-тың жұмысына жалпы жетекшілік жүргізуді Я.Полуянға әкімшілік, қаржы және шаруашылық мәселелерді, сондай-ақ ұйымдастыру бөлімі мен хатшылықтың жұмысын қадағалауды, С.Асфендияровқа жеке өтініштер мен арыздар бөліміне және Ұлттар бөліміне қатысты туындап отырған барлық мәселелерді шешуді тапсырды. С.Асфендияров БОАК Ұлттар бөлімінің меңгерушісі қызметінде 1927 жылы сәуірде өткен XIII Бүкілресейлік кеңестедің съезіне дейін жұмыс істейді. XIII шақырылымдағы БОАК-тың I сессияның қортындысында С.Асфендияров ұлттар бөлімі меңгерушісінің қызметін босатып, оған қазақ ұлтының тағы бір өкілі - Ә.Досов тағайындалы [9, б. 59 - 60].

1926-1927 жылдар аралығында, дәлірек айтқанда БКП (б) XIV съезінен Бүкілресейлік кеңестердің XIII съезіне дейін С.Асфендияров бар күш - жігерін РКФСР-да ұлттық территориалдық бірлестіктерді және ауылдық кеңестерді құру ісіне жұмылдырылған болатын. Өйткені, осы кезден бастап РКФСР-да аз санды ұлттарды жнргілікті басқару 
бірліктері - ұлттық ауылдық кеңестер арқылы кеңестендірудің ауқымды ісі қолға алынды. Бұл жұмыс ауқымы жағынан алғанда орасан зор еді, себебі Ресей Федерациясының барлық әкімшілдік - территориалдық бірліктерінде шашыраңқы орналасқан этникалық топтардың географиялық қоныстануын және болашақ әкімшілік - негіздеу , аудандастыруды жүзеге асыру, ic жүргізуге және мектеп бағадарламаларына ана тілін енгізу кеңес басшылығынан, С.Асфендияровтың жетекшілігіндегі ұлттар бөлімінен көп күш - қайрат жұмсауды талап етті. Сонымен қатар, С.Асфендияров жоғарыда аталған міндеттерді іске асыру барысында ұйымдастырушылық жұмыспен қана айналысып қоймай, күрделі саяси және әлеуметтік құбылыстарды ғылыми тұрғыдан негіздеумен де айналысты [9, б. 65].

Асфендияров 1928 жылдан бастап Қазақстанда еңбек етті: Абайатындағы педагогикалық институт болып қайта құрылған қазіргі Қазақ ұлттық педагогикалық университетінің алғашқы ректоры (1928-1931 ж.), Қазақ АКСР Денсаулық сақтау халкомы, Алматы медициналық институтының (қазіргі Қазақ ұлттық медициналық университеті) ұйымдастырушысы және тұңғыш ректоры (1931-1933 ж.) болды. Асфендияров осы институтта жалпы химия, биология, физика пәндерімен бірге анатомия, қалыпты физиология, ішкі аурулар, гистология, микробиология, фармакология, биологиялық химия, гигиена бөлімдерін және хирургиялық кафедраларын ашты. Асфендияров жұқпалы аурулармен күреске, аурулар мен індеттердің алдын алу шараларына, халыққа ақысыз дәрігерлік көмек көрсету жұмыстарын жолға қоюға көп еңбек сіңірді. Халық арасында жиі кездесетін өкпе, шешек, оба, сүзек, тері ауруларына қарсы медициналық көмек ісін ұйымдастырды. Орта дәрежелі оқу орындарында, қысқа мерзімді арнаульы курстарда әртүрлі буындағы медицина мамандарын көптеп даярлауға күш салды [8, б. 139-140].

Асфендияров Қазақстан тарихының күрделі мәселелерін зерттеген белгілі ғалым болды. Қазақ ұлттық мәдениет ғылыми-зерттеу институтының тарих секторының меңгерушісі, КСРО ҒА-ның Қазақстандық базасы, артынан бөлімшесі төрағасының орынбасары (1933-1937 ж.) қызметтерін атқарды.

Санжар Сейітжапарұлы жан - жақты даярлығы бар, жазбадеректерді терең білген, әмбебап тарихшы, ғалым. Ол жазған еңбектерді тақырыптық жағынан жіктер болсақ, оның шығармашылық ізденістерінен діннің шығу себептері, көшпелі шаруашылық, ұлттардың пайда болуы, тілдің рөлі, ұлт - азаттық қозғалыстары, «Қазан революциясының», республика партия ұйымының тарихы, ұлттық мәдениетті өркендету жолдары секілді қадау - қадау мәселелер арқау болғанын байқаймыз. Ол 1928 жылы жарық көрген «Исламның шығу себептері» атты еңбегінде жаңа қалыптаса бастаған Ислам мен кейінгі кезеңдердегі Ислам арасында принципті айырмашылықтар бар екенін дәлелдеуге тырысты. Кейінірек 1930 жылы осы мәселеге қайта айналып соғып, ислам дүниеге келген қоғамның әлеуметтік экономикалық құрылымын шаруашылықты материалистік тұрғыдан сипаттады.

С.Асфендияров кең ауқымды білімі мен тарихи - әдістемелік зерттеулерін ұштастыра отырып келесідей еңбектерді жазды: «История Казахстана с древнейших времен», «Прошлое Казахстана в источниках и материалах», «Национальное - освободительное восстание 1916 года в Казахстане» / монография. 1935-1936 жж. С.Асфендияров профессор П.А.Кунтемен бірлесіп «Прошлое Казахстана» атты екі томдық дереккөздер жтнағын жарыққа шығарды. Орта мектепке арналған «Қазақстан тарихының очерктері» жарық көрді. Бұл да Қазақстан тарихының деректану бөлімін байытты [10. б 4-5].

Санжар Асфендияровтың Қазақстан тарихына арналған тұңғыш оқу құралы ретінде «Қазақстан тарихының очерктер» еңбегі 1935 жылы жарық көрген болатын. Алайда 1937 жылы С.Асфендияровтың репрессияға ұшырауына байланысты еңбек оқырмандар қолына тимей қалды. Оқу құралында ерте заманнан бастап 1917 жылға дейінгі қазақ елінің тарихы деректі материалдармен және құжаттармен жан - жақты баяндалған. Онда «Қазақ» атауының шығуы жөнінде, қазақ халқының ұлт болып қалыптасуы туралы кең мағлұмат берілген. 
1935 жылы тоталитарлық идеология негізінде жазылған «Қазақстан тарихы (көне дәуірден бастап)» еңбегінде М.Тынышбаевтың қазақ хылқының шығу тегі туралы ғылыми еңбегін ұлтшыл - буржуазиялық теория жасаған деп айыптап, «М.Тынышбаевтың еңбегі жартылай феодалдық және буржуазиялық, байшылдықтың, тұрпайы ұлттық шовинизмнің көрнекті мысалы » - деп , теріс баға береді [10, б. 5].

1935-1936 жж. С.Асфендияровтың П.А.Кунтемен бірлесіп жазған «Прошлое Казахстана» атты екі томдық дереккөздер жинағында қазақтардың тарихы мен тұрмысын, қазақтардың көрші мемлекеттермен және халықтармен өзара қатынасын және орыстардың Шығасқа отаршылдық басқыншылығының алғашқы он жылының тарихын бейнелейтін материалдар топтастырылған.

Профессор С.Асфендияров Қазақстан тарихының негізін қалағанын және оны орта мектептер мен жоғары оқу орындарында оқыту ісін қолға алғанын ерекше атауымыз керек. Ол Қазақстан тарихын түгел қамтып, бір жүйеге келтірді. Ол «Қазақстан тарихының» 2 томын жазды. Аталған жұмыста алғаш рет қазақ халқының ежелгі кезеңнен 1917 жылға дейінгі тарихы жүйелі түрде жазылған. Ол капиталистік кезеңге дейінгі қазақтар арасында таптық қатнастардың қалай пайда болғандығы және дамығандығымен және дамудың осы сатысындағы қазақ қоғамындағы экономикалық дамудың нақты ерекшеліктері қандай болғандығымен байланысты бірқатар мәселелер қойды.

С.Асфендяиров революцияға дейінгі Қазақстан тарихын шартты түрде екі кезеңге бөледі: 1) патшалық Ресейдің басып алуына дейінгі қазақтар тарихы (XVIII ғасырға дейін); 2) Қазақстан ресейлік империализмнің отары ретінде (XVIII-XIX ғ.ғ.). Еңбегінің екінші бөлімінде Асфендияров «ресей капитализмі басқыншылығының қазақ қоғамының одан арғы қалыптасуына ықпалын, жаңа негіздегі таптық қарама -қайшылықтардың өсуін, империализм және пролетарлық революция жағдайында ұлттық - революциялық қозғалыстардың қозғаушы күшінің дамуын, яғни Қазақстандағы Қазан революциясының алғышарттарының дамуын» көрсетуге тырысты [10, б. 5-6].

Монографияның қазақ халқының шығуы туралы бөлімінде автор «хылық ұғымы биологиялық емес, ал әлеуметтік» екендігін атап көрсетеді және оқырманнан қазақ халқынан әлдеқайда бұрын қалыптасқан ежелгі үйсіндер мен, наймандармен, қыпшақтармен және басқа да тайпалармен араластырмаудан сақтандырады.

Автордың тағы бір құнды кітабы «Қазақстандағы 1916 жылғы ұлт - азаттық көтеріліс». Бұл ғылыми еңбектің негізгі маңызы - патша үкіметінің қазақ жерлерін отарлау саясатының бетпердесін жеріне жеткізе ашатындығында.

\section{Қорытынынды}

1937-1938 жылдардағы сталиндік қуғын - сүргін С.Асфендияровты да, оның жанұясын да айналып өтпеді. 1938 жылы 25 ақпанда ол атылып, қазіргі Алматы облысының Жаңалық ауылында өзге қазақ зиялыларымен бірге жерленді. Оның өмірлік серігі, Мемлекеттік көпшілік кітапханада бөлім басшысы болып қызмет еткен Рабиға Сералықызы «халық жауының жұбайы» ретінде 10 жылға сотталып, Ақмоладағы Отан сатқындары әйелдерінің лагеріне айдалды. Санжар мен Рабиғаның қыздары - Әлия мен Адаляттың тағдырлары тәлкекке түсіп, өмірдің бар ауыртпалығын бастан кешірді. Олар анасы Рабиғамен тек 1954 жылы ғана қайта қауышты. Р.Асфендиярова 1958 жылы 31 наурызда КСРО Жоғарғы Сот Әскери коллегиясының шешімімен ақталып, өзінің жұбайы Санжардың ақталуын көретін бақытты күнге бірнеше күн жете алмай , 4 мамырда ауыр науқастан көз жұмды. С.Асфендияров 1958 жылы 27 мамырда КСРО Жоғарғы Сот Әскери коллегиясының шешімімен толық ақталды.

С.Асфендияровтың есімімен Қазақстандағы академиялық ғылымның, жоғары білім беру жүйесінің, мәдениет пен оқу - ағарту салаларының толықтай бір даму кезеңі байланысты. Оның еңбегінің көмегімен елімізде жоғары оқу орындары мен ғылыми зерттеу оратлықтары, кітапханалар мен мектептер, музейлер ашылып, Қазақстан тарихының 
өзекті мәселелеріне арналған кешенді зерттеу еңбектері, көлемді ғылыми мақалалар жарық көріп, қазақ халықының бай рухани және материалдық мұрасы жинақталды.

\section{ӘДЕБИЕТ}

[1] Сулейменов Р.Б. О научной деятельности С.Д.Асфендиярова // Сулейменов Р.Б. / Вестник АН КазССР. - 1959. - №12. - С. 101 - 102.

[2] Сулейменов Р.Б. Видный общественный деятель и ученый // Алма - Атинская правда. - 1959. - 24 октября, №14.

[3] Жүнісбаев А. Санжар Асфендияров: өмірі мен қызметі (1889 - 1938жж.) T 1: (1889 - 1918жж.) / Жүнісбаев А. - Алматы: Елтаным баспасы, 2014. - 256 + 12 бет суретті жапсырма.

[4] Алматы. Эничиклопедия. - Алма - Ата: Главная редакция Казахской советской энцииклопедии, 1983. - С.127.

[5] Әлжсанов А. Алвашқы қ̧азақ дәрігерлері. / Әлжанов А., Шокин А., Досаханов Ә. Алмать: Қазақстан, 1984. Бб. 69 - 70 б.

[6] Библиография обществоведов Казахстана. - Алма-Ата: Наука, 1986. - С. 475.

[7] Қоңыратбаев О.М. Мені таңұzалдырzан тұлвалар: Ахмет Байтұрсынов (1872 1938 жж.), Санжар Асфендияров (1889-1938 жж.), Тұрар Рысқұлов (1894-1938 жж.) / Қоньыратбаев О.М., Жүрсінбаев Б.А., Жүнісбаев А.Ә. - Алматы: Нұр-Принт 75, 2011. - 328 б.

[8] Көпішев Ә.С. Қазақ халқының тарихи тұлвалары: Қысқаша анықтамалық.. / Көпішев Ә.С. және т.б., 2 -кітап. - Алматы: Өнер, 2013.- 360 б.

[9] Жүнісбаев А. Санжар Асфендияров - РКФСР БОАК төралқасы жанындавы ұлттар бөлімінің мензгерушісі. (1925-1927 жж.) // Жүнісбаев А. - Қазақсттан мұраваттары - 2014. - №1(29) бб. $58-71$.

[10] Санжар Сейітжапарұль Асфендияровтың туванына 125 жыл (1889-1938 жж.) / Педагогикальқ диалог - 2014. - №4(10), бб. 200 - 201.

\section{REFERENCES}

[1] Sulejmenov R.B. (1959). O nauchnoj dejatel'nosti S.D.Asfendijarova [About the scientific activity of S. D. Asfendiyarov]. Vestnik AN KazSSR - Bulletin of the Academy of Sciences of the Kazakh SSR, 12, 101 - 102 [in Russian].

[2] Sulejmenov R.B. (1959, 24 October) Vidnyj obshhestvennyj dejatel' $i$ uchenyj [A prominent public figure and scientist]. Alma - Atinskaja Pravda - Alma-Ata truth [in Russian].

[3] Júnisbaev A. (2014). Sanjar Asfenduarov: ómiri men qyzmeti (1889 - 1938jj.) [Sanzhar Asfendiyarov: life and work (1889 - 1918)] (Vols. 1). Almaty: «Eltanym baspasy» [in Kazakh].

[4] Almaty. Jenciklopedija. [Almaty. Encyclopedia]. (1983). Glavnaja redakcija Kazahskoj sovetskoj jenciklopedii - The main edition of the Kazakh Soviet Encyclopedia, Alma - Ata [in Russian].

[5] Áljanov A., Shokın A., Dosahanov Á (1984). Alǵashqy qazaq dárigerleri [The first Kazakh doctors]. Almaty: «Kazakhstan», 69 - 70 [in Kazakh].

[6] Bibliografija obshhestvovedov Kazahstana [Bibliography of social scientists of Kazakhstan] (1986). Alma - Ata: Nauka, 40 - 41[in Russian].

[7] Qońyratbaev O.M., Júrsinbaev B.A., Júnisbaev A.Á. (2011) Meni tańǵaldyrǵan tulǵalar: Ahmet Baltursynov (1872 - 1938 jj.), Sanjar Asfendıarov (1889 - 1938 jj.), Turar Rysqulov (1894 - 1938 jj.) [I was surprised by the personalities: Akhmet Baitursynov (1872-1938).), Sanzhar Asfendiyarov (1889-1938.), Turar Ryskulov (1894-1938.)]. Almaty: Nur-Print75 [in Kazakh]. 


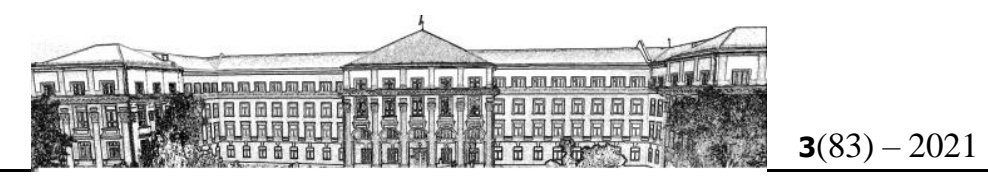

[8] Kópishev Á.S. et al. (2013) Qazaq halqynyń tarthı tulǵalary: Qysqasha anyqtamalyq [Historical figures of the Kazakh people: a brief reference book] (Book 2). Almaty: «Óner» [in Kazakh].

[9] Júnisbaev A. (2014). Sanjar Asfendıarov - RKFSR BOAK tóralqasy janyndaǵy ulttar bóliminiń meńgerýshisi. (1925-1927 jj.) [Sanzhar Asfendiyarov-head of the Department of nationalities under the Presidium of the BOAC of the RSFSR. (1925 - 1927)] Qazaqstan muraǵattary, 1(29) 58 - 71 [in Kazakh].

[10] Sanjar Selitjaparuly Asfenduarovtyń týǵanyna 125 jyl (1889 - 1938 jj.) [125 years since the birth of Sanzhar Seitzhaparovich Asfendiyarov (1889-1938)] (2014). Pedagoglkalyq dialog, 4(10) 200 - 201 [in Kazakh].

\section{Рысбеков Т.3., Куандихова С.А. ЖИЗНЕННЫЙ ПУТЬ И ДЕЯТЕЛЬНОСТЬ САНЖАРА АСФЕНДИЯРОВА}

Аннотация. В статье рассказывается о жизни и деятельности Санжара Асфендиярова, великого казахского общественного и государственного деятеля, дальновидного политика, талантливого ученого, педагога, писателя, знатока и искусного организатора науки и образования в Казахстане. Его вклад в становление и развитие казахской государственности, в систему образования и науки, в здравохранение велика.

Санжар Асфендияров - продолжение казахской элиты. Отец Сейтжапар - султан, ушедший в отставку в звании полковника царской армии из потомства старшего сына Абулхайыр хана Айшуак хана, более полувека проработавший в Туркестанском крае казахский деятель, мать его звали - Гкльданам Касымова. Начав свою более чем полувековую карьеру с рядового порукчика, Санжар Асфендияров благодаря врожденному таланту и трудолюбию добивается высокого воинского звания для тюрко - мусульманских народов Туркестанского края - звания полковника. Грамотный, открытый Санжар Асфендияров стремился дать своим детям лучшее образование.

Ключевые слова: историческая наука, ученый, врач, исследование, сочинение, монография, педагог, политик, ссср, политика.

\section{Rysbekov Tuyakbai, Kuandikhova Sabina \\ THE LIFE PATH AND ACTIVITY OF SANZHAR ASFENDIYAROV}

Annotation. The article describes the life and work of Sanzhar Asfendiyarov, a great Kazakh public and statesman, a visionary politician, a talented scientist, teacher, writer, expert and skilful organizer of science and education in Kazakhstan. His contribution to the formation and development of the Kazakh statehood, to the system of education and science, to health care is great.

Sanzhar Asfendiyarov is a continuation of the Kazakh elite. The father of Seitzhapar-Sultan, who retired with the rank of colonel of the tsarist army from the offspring of the eldest son of Abulkhayir Khan Aishuak Khan, a Kazakh figure who worked in the Turkestan region for more than half a century, his mother's name was Gkldanam Kasymova. Having started his more than half-century career as an ordinary lieutenant, Sanzhar Asfendiyarov, thanks to his innate talent and hard work, achieves a high military rank for the Turkic-Muslim peoples of the Turkestan region - the rank of colonel. The literate, open-minded Sanjar Asfendiyarov sought to give his children the best education.

Keywords: Historical science, scientist, doctor, research, essay, monograph, teacher, politician, ussr, policy. 